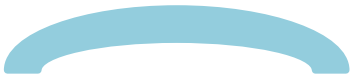

\title{
Variations of Formation, Distribution and Communications of Median Nerve in Fetal Cadavers
}

\author{
Fetal Kadavralarda Nervus Medianus’un Oluşumu, Dallanması ve \\ Anastomozlarının Varyasyonları \\ Kenan ÖZTÜRK ${ }^{1 *(1)}$, Büşra CANDAN ${ }^{2(0)}$ Ahmet DURSUN ${ }^{10}$ Yadigar KASTAMONi ${ }^{10}$ Selçuk TUNALI ${ }^{3(0)}$ \\ Soner ALBAY 1 (1)
}

\author{
${ }^{1}$ Suleyman Demirel University, Faculty of Medicine, Department of Anatomy, Isparta, Turkey \\ ${ }^{2}$ Alaaddin Keykubat University, Faculty of Medicine, Department of Anatomy Alanya, Turkey \\ ${ }^{3}$ TOBB University of Economics and Tecnology, Faculty of Medicine, Department of Anatomy Ankara, Turkey.
}

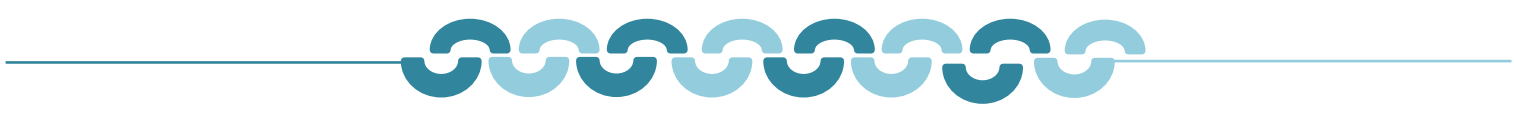

\section{A B S T R A C T}

Objective: Variations of the median nerve $(\mathrm{MN})$ are important for clinical and surgical approaches. In this study, it was aimed to determine the formation, distribution and communication of the MN in fetal cadavers.

Material and Method: This study was carried out on 80 upper extremities obtained from 40 spontaneously aborted human fetuses (22 females, 18 males) aged between 18 and 40 weeks. Median, ulnar and musculocutaneous nerve (MSCN) and their branches were identified and distribution of their branches was determined. The distribution, formation and communications of the MN were examined.

Results: In this study, it was seen that the MN was composed of three roots in the $6(7.5 \%)$ of 80 upper limbs. It was also found that the MN innervated the flexor muscles of the arm in two extremities despite MSCN was present $(2.5 \%)$. It has also been determined that the $\mathrm{MN}$ innervated the flexor muscles of the arm in one extremity where MSCN was absent (1.25\%). In addition, communications between the MSCN and the MN was detected in $3(3.75 \%)$ extremities. Finally, in our study, Martin-Gruber communication was found $3.75 \%$ while Marinacci communication was not determined.

Conclusions: This study identified variations and communications of the MN by means of fetal cadaveric dissection. These variations will adversely affect the correct diagnosis and treatment planning in upper extremity injuries. Therefore, precise knowledge of the variations and communications of the MN will be useful for surgeons to avoid iatrogenic injuries during surgical interventions in this region.

Keywords: Fetus, marinacci communication, martin-gruber communication, musculocutaneous nerve, ulnar nerve

Alınış / Received: 20.04.2021 Kabul / Accepted: 29.07.2021 Online Yayınlanma / Published Online: 20.12.2021 


\section{$\operatorname{sen} 202$}

\section{Ö Z E T}

Amaç: Nervus medianus'un varyasyonları klinik ve cerrahi yaklaşımlar açısından önemlidir. Bu çalışmanın amacı, fetal kadavralarda nervus medianus'un oluşumunu, dallanmasını ve anastomozlarını belirlemektir.

Materyal-Metod: Bu çalışma, Süleyman Demirel Üniversitesi Tıp Fakültesi Anatomi Anabilim Dalı laboratuvarında bulunan yaşları 18-40 gebelik haftası arasında değişen ve eksternal anomali ya da patolojisi olmayan 40 (22 dişi, 18 erkek) fetal kadavraya ait 80 üst ekstremite üzerinde gerçekleştirildi. Nervus medianus, $n$. ulnaris ve $n$. musculocutaneus'un dalları tanımlanarak bu dalların dağılımı belirlendi. Nervus medianus'un dallanması ve oluşumu ile onun anatomozları incelendi.

Bulgular: Bu çalışmada n. medianus'un 80 üst ekstremitenin 6'sında $(\% 7,5)$ üç kökten oluştuğu görüldü. Nervus medianus'un, 2 (\%2,5) ekstremitede, n. musculocutaneus mevcut olmasına rağmen kolun fleksor komparmanındaki kasları innerve ettiği görüldü. Nervus musculocutaneus'un olmadığı $1(\% 1,25)$ ekstremitede ise n. medianus'un kolun fleksor komparmanındaki kasları innerve ettiği görüldü. Ayrıca 3 ekstremitede $(\% 3,75) \mathrm{n}$. musculocutaneus ile n. medianus arasında anastomoz saptandı. Son olarak çalışmamızda \%3,75 oranında Martin-Gruber anastomozu bulunurken Marinacci anatomozuna rastlanmamıştır.

Sonuç: Bu çalışmada, fetal kadavra diseksiyonu ile n. medianus'un varyasyonları ve anastomozları tanımlandı. $\mathrm{Bu}$ varyasyonlar üst ekstremite yaralanmalarında doğru tanı ve tedavi planlamasını olumsuz etkileyecektir. Bu nedenle, n. medianus'un varyasyonları ve anastomozları hakkında yeterli bilgi sahibi olunması, cerrahların bu bölgeye yapılan müdahaleler sırasında iyatrojenik yaralanmalardan kaçınması için yararlı olacaktır.

\section{Introduction}

The brachial plexus, which has a very complex structure, is adjacent to important anatomical structures. Therefore, it is important to know the variations of the brachial plexus clinically and surgically [1].

The median nerve $(\mathrm{MN})$ is formed by the medial and lateral roots, respectively, originating from the medial and lateral fascicle of the brachial plexus [2]. Variations in the occurrence of MN have been reported by some authors [2-4].

The lateral fascicle of the brachial plexus is usually divided into the musculocutaneous nerve (MSCN) and the lateral root of the MN. As a variation, some of the fibers corresponding to the MN may run together with MSCN and then split up and join the MN. Less frequently, some fibers of the MSCN may run in the $\mathrm{MN}$, then leave it and join their proper trunk [5].

The MN runs downwards on the medial side of the arm. It crosses the brachial artery from lateral to medial and passes in front of the elbow joint and enters the forearm. MN usually does not give branches to the muscles on the front of the arm [6]. However, some authors reported that the MN innervates the arm flexors [7].

The MSCN innervates all the muscles in the front of the arm. As a variation, fibers of the MSCN may run in the MN and MN supplies flexor muscles of the arm and skin of lateral side of the forearm [6]. 
Previous studies have reported that the MN may connect to the ulnar nerve (UN) in the forearm. Median-ulnar communication in the forearm was first described by Martin in 1763, and later by Gruber in 1870. This communication was later referred as Martin-Gruber communication (MGC). The incidence of MGC ranges from $5 \%$ to $40 \%$. Sometimes, a communicating branch may extend from UN to $\mathrm{MN}$, which is known as the opposite of the MGC, ulnar-to-median communication or Marinacci communication (MC) [8].

In this study, it was aimed to determine the formation, distribution and communication of the MN in fetal cadavers.

\section{Material and Method}

This study was carried out on 80 upper extremities belonging to 40 human fetuses ( 22 females, 18 males) aged between 18 and 40 weeks of gestation, with no external anomaly or pathology, in the laboratory of Suleyman Demirel University, Faculty of Medicine, Department of Anatomy.

Initially, skin and superficial fascia were removed, muscles and nerves of the forearm and arm were exposed. Then, MN, UN, MSCN and their branches were identified and their distribution was determined. The distribution, formation and communications of the MN were examined. Dissections were performed with $\times 10$ magnification using the binocular digital stereo microscope (EUROMEX Edublue 1805-S, Netherlands).

\section{Results}

In our study, it was seen that the MN was composed of three roots in $6(7.5 \%)$ of 80 upper extremities. Third root arose from medial fascicle at the brachial plexus in 2 extremities (2.5\%) (Figure 1a) and from lateral fascicle in 4 extremities (5\%) (Figure 1b).

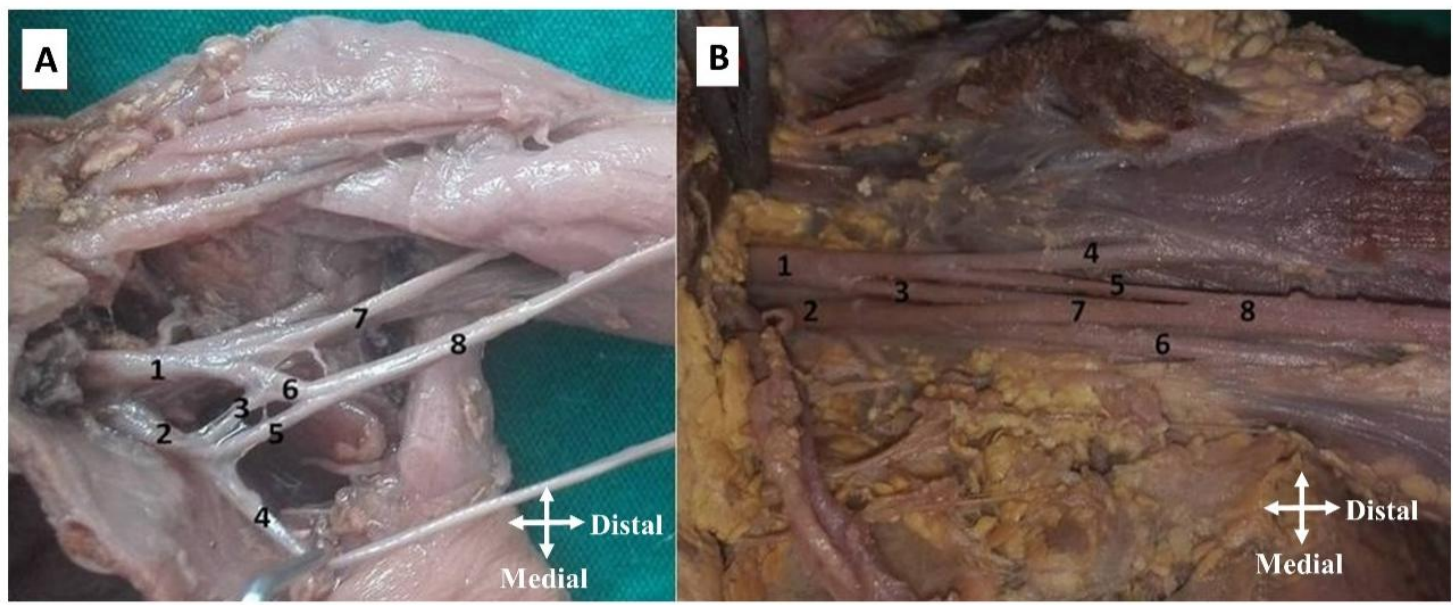

Figure 1: Median nerves consisting of three roots (left side). a. Lateral fascicle (1), medial fascicle (2), third root of the median nerve (3), ulnar nerve (4), medial root of the median nerve (5), lateral root of the median nerve (6), musculocutaneous nerve (7), median nerve (8). b. Lateral fascicle (1), medial fascicle (2), third root of the median nerve (3), musculocutaneous nerve (4), lateral root of the median nerve (5), ulnar nerve (6), medial root of the median nerve (7), median nerve (8)

It was found that the MN innervated the flexor muscles of the arm in two extremities (2.5\%) although MSCN was present. In one extremity (1.25\%), MN innervated the flexor muscles of the arm where MSCN was absent (1.25\%) (Figure 2). 


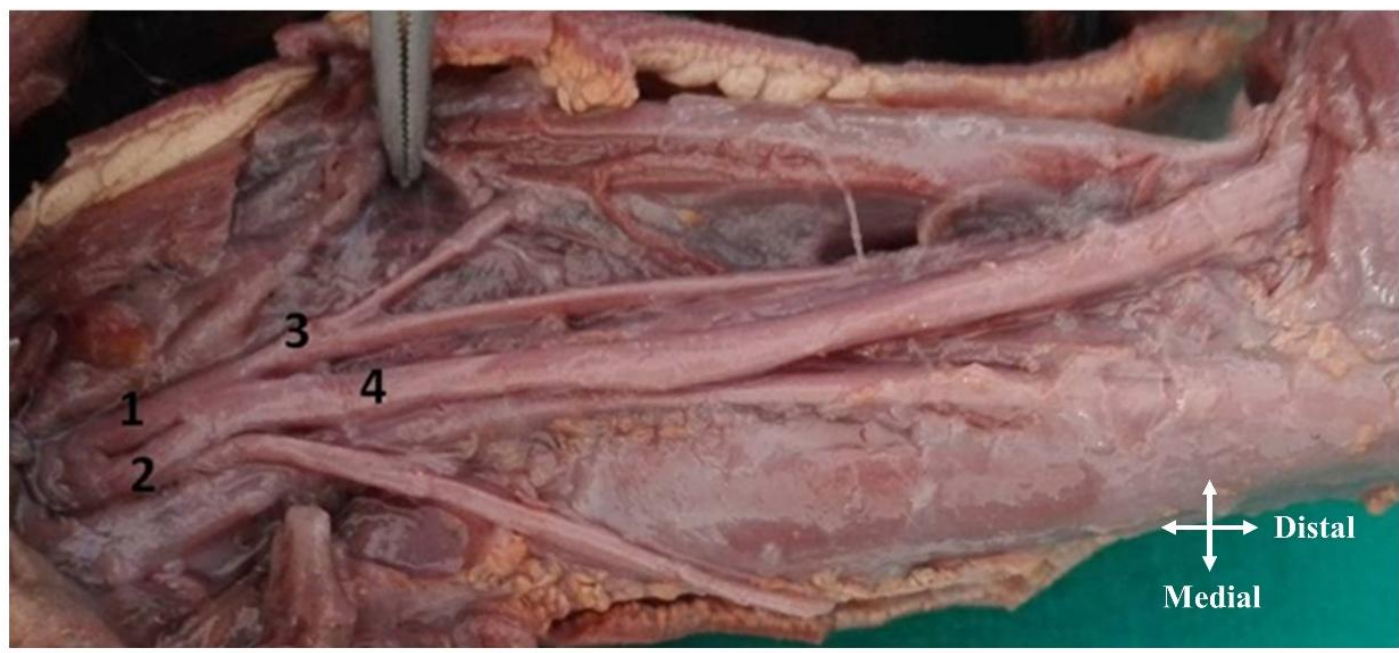

Figure 2: Photograph showing branches to the arm flexors from the median nerve in absence of musculocutaneous nerve. Lateral root (1), medial root (2), branch to the arm flexors (3), median nerve (4)

When we investigated MN's communication with MSCN, we detected communications in three extremities (3.75\%) (Figure 3). Finally, MGC was determined in 3 extremities, while MC was not determined at all (Figure 4).

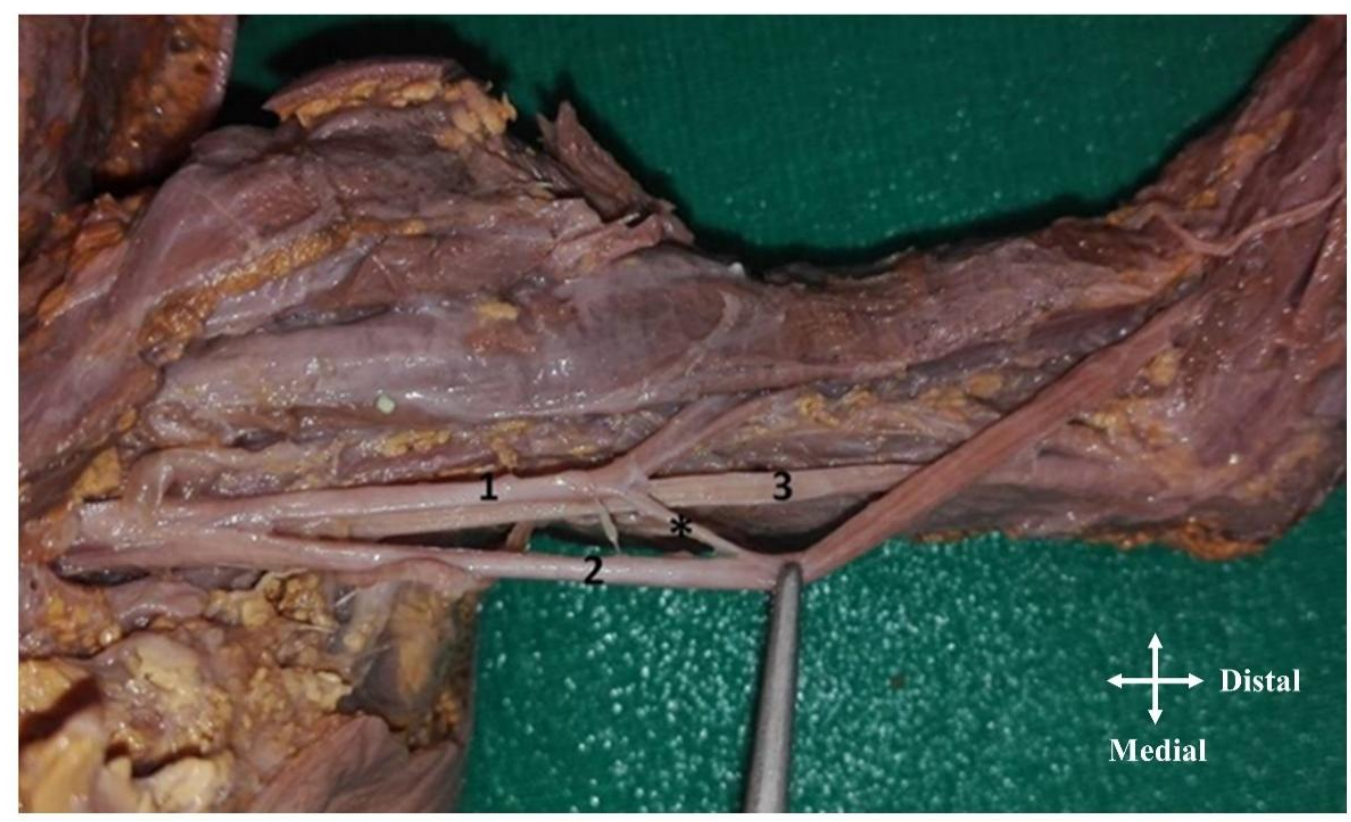

Figure 3: Photograph showing communication of the median and musculocutaneous nerve. Musculocutaneous nerve (1), median nerve (2), ulnar nerve (3), communication branch ( $\left.{ }^{*}\right)$ 


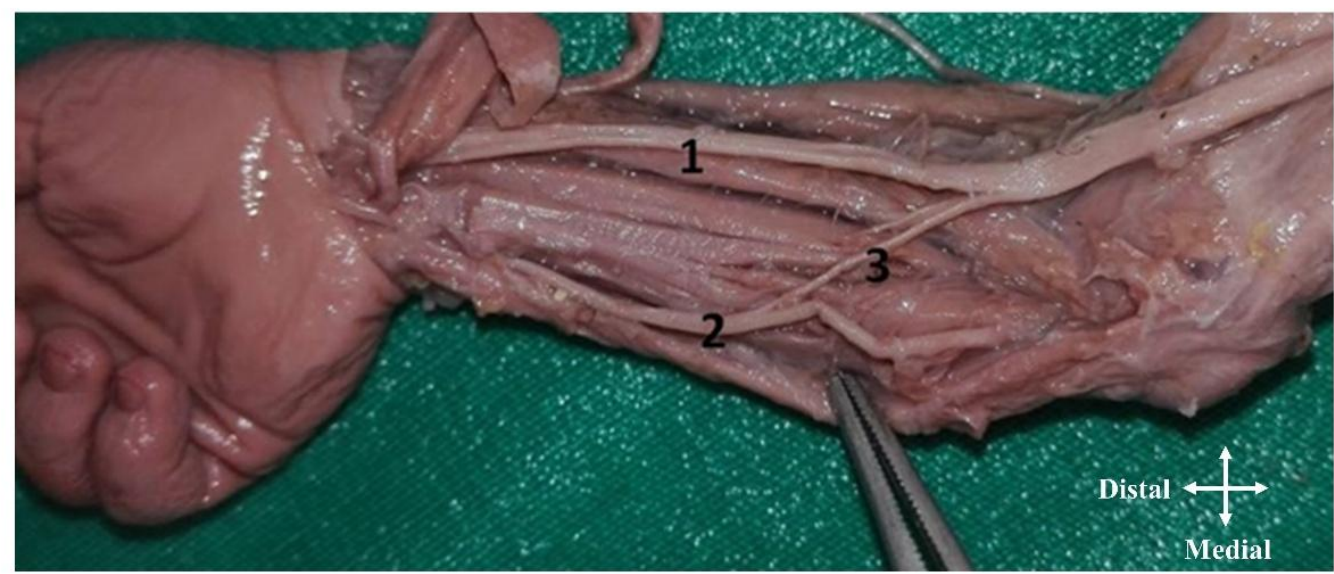

Figure 4: Median nerve (1), ulnar nerve (2), Martin-Gruber communication (3)

\section{Discussion and Conclusion}

\section{Discussion}

Unusual connection of the MN to other nerves such as MSCN and UN [9], variations in the formation of the MN, $[2-4,10]$ and unusual innervation of the arm flexor muscles by the MN were reported earlier by some authors [2,11]. Budhiraja et al [2] reported that in $22 \%$ upper limbs; MN had three roots. In their study, the third root originated from lateral fascicle of the brachial plexus in $14 \%$ of the upper limbs, and from MSCN in $8 \%$ of the upper limbs. In addition, in $3.6 \%$ upper limbs, MN was reported to be formed by four roots; two from lateral fascicle, one from medial fascicle and one from MSCN. Sontakke et al [10] described a case where MN was formed by three roots; two of roots came from lateral fascicle and one from medial fascicle. Ramachandran et al [12] reported that third root of the MN was coming from MSCN in their case. Satyanarayana et al [3] reported a case that MN was formed by three roots (two roots from lateral fascicle and one from medial fascicle). In the previous studies, it was reported that the third root of the MN came from the lateral fascicle more frequently. These results are similar to our study. The rates Budhiraja et al [2] reported as a result of their study were different than ours. The reason for this may be that the races studied on are different.

Variations in the formation of the $\mathrm{MN}$ are important in surgical procedures in the axillar region. These variations may lead to failure of nerve blockage in this region.

The communication between the MSCN and the MN is one of the most common variation observed among the brachial plexus branches [13]. In previous studies, [13-18] the incidence of connections between MSCN and MN has been reported between $1.4 \%$ and $54 \%$ (Table 1). 
Table 1. Frequency of communications of the median and musculocutaneous nerve in our study and previous studies

\begin{tabular}{lc}
\hline Author & Frequency (\%) \\
\hline Arquez, 2015 & 7.6 \\
Guerri-Guttenberg and Ingolotti, 2009 & 53.6 \\
Maeda et al., 2009 & 41.5 \\
Mariya, 2013 & 6.6 \\
Venieratos and Anagnostopoulou, 1998 & 13.9 \\
Wantanabe et al., 1985 & 1.4 \\
Our study & 3.8 \\
\hline
\end{tabular}

The results of previous studies are quite different from each other and from the results of our study. The reason for this may be that the races of the samples studied are different.

It is important for clinical practice to know the existence of the communication between MSCN and MN. In order to avoid undesirable consequences of operations carried out on the MSCN, it is recommended that MN and MSCN communications should be removed [9].

Ihunwo et al (19) reported a case of absence of the MSCN bilaterally and arm flexors were innervated by branches from the MN. Similarly, Gumusburun and Adiguzel [7] observed bilateral absence of MSCN. The MN innervated the biceps brachii and brachialis muscles instead of MSCN in their case. Sud and Sharma [20] reported a case of absence of the MSCN with innervation of the coracobrachialis, brachialis and biceps brachii muscles by the MN. Prasada Rao and Chaudhary [21] found absence of the MSCN in 2 out of 24 upper limbs (8\%). The MN took over the function of MSCN by giving off both muscular and sensory branches. In the studies above, only Prasada Rao and Chaudhary [21] reported the rate of innervation of the arm muscles by MN when MSCN is absent. In our study, it was found that the MN innervated the flexors of the arm in two extremities despite MSCN was present $(2.5 \%)$. It was also determined that the $\mathrm{MN}$ innervated the flexors of the arm in one extremity where MSCN was absent (1.25\%). The possibility of the MN innervating the arm flexors should be considered whena patient with MN damage in the axilla or proximal arm shows weakness in forearm flexion and supination [22].

The incidence of the MGC differs between physiological and anatomical studies. In physiological studies, its occurring rate reported as $5-40 \%,[8,23,24]$ whereas anatomical studies report a narrower range of $10-31 \%$ [25-29]. Sarikcioglu et al. [8] studied on 30 preserved forearms by dissection and 60 forearms of 30 patients by electrophysiological technique and they found MGC less $(6.6 \%$ and $3.3 \%$ of forearms, respectively) frequently than reported in the literature. In fetuses, its incidence was reported as $15 \%$ by Srinivasan and Rhodes [30] and $7.5 \%$ by Dogan et al. [31] The results of our study are similar to the results of the studies of Sarikcioglu et al (2003) and Dogan et al. [31] This may be because the races studied on are the same.

Although MC is not as common as MGC, it is not uncommon in electrophysiological studies [32]. Frequency of Marinacci communication was found as $1.3 \%$ by Kimura et al [33], $4 \%$ by MeenakshiSundaram et al. [34], 17\% by Golovchinsky [35]. But in someother electrophysiological studies, MC wasn't detected $[8,36]$. So far, MC has not been observed in cadaveric studies. Similarly, MC was not detected in our study.

The MGC has clinical significance in the assessment of median nerve lesion, the carpal and cubital tunnel syndrome and neuropathies [27]. Although the neural communications between UN and MN are very rare in the forearm, it is important to know these connections for correct diagnosis of the neuropathies and surgical interventions in this area.

\section{Conclusion}

This study identified variations and communications of the MN by means of fetal cadaveric dissection. In conclusion, anatomic variations of the peripheral nerves are important for clinical and surgical 
approaches. These variations will adversely affect the correct diagnosis and treatment planning in upper extremity injuries. Therefore, precise knowledge of the variations and communications of the MN will be useful for surgeons to avoid iatrogenic injuries during surgical interventions in this region.

\section{References}

[1] Dursun A, Bilkay C, Albay S. A rare variation in the branching pattern of posterior cord. Int $J$ Anat Var.2016;9:29-31.

[2] Budhiraja V, Rastogi R, Asthana AK. Anatomical variations of median nerve formation: Embryological and clinical correlation. J Morphol Sci. 2011;28:283-6.

[3] Satyanarayana N, Vishwakarma N, Kumar GP, Guha R, Dattal AK, Sunitha P. Rare variations in the formation of median nerve-embryological basis and clinical significance. Nepal Med Coll J.2009;11:287-90.

[4] Uzun A, Seelig LL. A variation in the formation of the median nerve: communicating branch between the musculocutaneous and median nerves in man. Folia Morphol.2001;60: 99-101.

[5] Ballesteros LE, Forero PL, Butrago ER. Communication between the musculocutaneous and median nerves in the arm: an anatomical study and clinical implications. Rev Bras Ortop.2015;50:567-72.

[6] Candan B, Öztürk K, Albay S. Bilateral absence of musculocutaneous nerve with unusual communicating branch between radial and ulnar nerves. Int J Anat Var.2016;9:39-42.

[7] Gümüşburun E, Adıgüzel E. A variatiaon of the brachial plexus characterized by the absence of the musculocutaneous nerve: a case report. Surg Radiol Anat.2000;22:63-5.

[8] Sarıkçıŏlu L, Sindel M, Özkaynak S, Aydın H. Median and ulnar nerve communication in the forearm: an anatomical and electrophysiological study. Med Sci Monit.2003;9:351-6.

[9] Chauhan R, Roy TS. Communication between the median and musculocutaneous nerve- a case report. J Anat Soc India.2002;51:72-5.

[10] Sontakke BR, Tarnekar AM, Waghmare Je, Ingole IY. An unusual case of asymmetrical formation and distribution of median nerve. Int J Anat Var.2011;4:57-60.

[11] Nayak S. Absence of musculocutaneous nerve associated with clinically important variations in the formation, course and distribution of the median nerve - a case report. Neuroanatomy.2007;6:49-50.

[12] Ramachandran K, Kanakasabapathy I, Holla SJ. Multiple variations involving all the terminal branches of the brachial plexus and the axillary artery - a case report. Eur J Anat.2006;10:61-6.

[13] Venieratos D, Anagnostopoulou S. Classification of communications between the musculocutaneous and median nerves. Clin Anat.1998;11:327-31.

[14] Arquez HF. Communication between the median and musculocutaneous nerve. An anatomical study. Int $\mathrm{J}$ Pharma Bio Sci. 2015;6:951-7.

[15] Guerri-Guttenberg RA, Ingolotti M. Classifying musculocutaneous nerve variations. Clin Anat.2009;22:67183.

[16] Maeda S, Kawai K, Koizumi M, Ide J, Tokiyoshi A, Mizuta H, Kodama K. Morphological study of the communication between the musculocutaneous and median nerves. Anat Sci Int. 2009;84:34-40.

[17] Mariya NJ. Patterns of communications between musculocutaneous and median nerve: a cadaveric study. Int J Med Res Heal Sci.2013;2:425-30.

[18] Wantanabe M, Takatsujı K, Sakamoto N, Morit $\mathrm{Y}$, Ito $\mathrm{H}$. Two cases of fusion of the musculocutaneous and median nerves. Kaibogaku Zasshi, 1985;60:1-7.

[19] Ihunwo AO, Osinde SP, Mukhtar AU. Distribution of median nerve to muscles of the anterior compartment of the arm. Cent Afr J Med.1997;43:359-60.

[20] Sud M, Sharma A. Absence of musculocutaneous nerve and the innervation of coracobrachialis, biceps brachii and brachialis from the median nerve. J Anat Soc India.2000; 49:176-7.

[21] Prasada Rao PVV, Chaudhary SC. Absence of musculocutaneous nerve: two case reports. Clin 


\section{Anat.2001;14:31-5.}

[22] Beheiry EE. Anatomical variations of the median nerve distribution and communication in the arm. Folia Morphol.2004;63:313-8.

[23] Crutchfield CA, Gutmann L. Hereditary aspects of median-ulnar nerve communications. J Neurol Neurosurg Psychiatry.1980;43:53-5.

[24] Lee KS, Oh CS, Chung IH, Sunwoo IN. An anatomic study of the Martin-Gruber anastomosis: electrodiagnostic implications. Muscle Nerve.2005;31:95-7.

[25] Kawashima T, Sato K, Sasaki H. Stratification of the flexor retinaculum and the course and distribution of the ulnar, median, and palmar digital nerves: an anatomical study. Clin Anat.2004;17:643-50.

[26] Nakashima T. An anatomic study on the Martin-Gruber anastomosis. Surg Radiol Anat.1993;15:193-5.

[27] Rodriguez-Niedenfuhr M, Vazquez T, Parkin I, Logan B, Sanudo JR. Martin-Gruber anastomosis revisited. Clin Anat. 2002;15:129-34.

[28] Shu HS, Chantelot C, Oberlın C, Alnot JY, Shao H. Martin-Gruber communicating branch: Anatomical and histological study. Surg Radiol Anat.1999;21:115-8.

[29] Taams KO. Martin-gruber connections in South Africa: an anatomical study. J Hand Surg $\mathrm{Br}$ Eur Vol.1997;22:328-30.

[30] Srinivasan R, Rhodes J. The median-ulnar anastomosis (Martin-Gruber) in normal and congenitally abnormal fetuses. Arch Neurol. 1981;38:418-9.

[31] Doğan NU, Uysal II, Karabulut AK, Fazlığulları Z. The motor branches of median and ulnar nerves that innervate superficial flexor muscles: A study in human fetuses. Surg Radiol Anat.2010;32:225-33.

[32] Unver Doğan N, Uysal II, Şeker M. The communications between the ulnar and median nerves in upper limb. Neuroanatomy.2009;8:15-9.

[33] Kimura I, Ayyar DR, Lippmann SM. Electrophysiological verification of the ulnar to median nerve communications in the hand and forearm. Tohoku J Exp Med.1983;141:269-74.

[34] Meenakshi-Sundaram S, Sundar B, Arunkumar MJ. Marinacci communication: an electrophysiological study. Clin Neurophysiol.2003;114:2334-7.

[35] Golovchinsky V. Ulnar-to-median anastomosis and its role in the diagnosis of lesions of the median nerve at the elbow and the wrist. Electromyogr Clin Neurophysiol.1990;30:31-4.

[36] Amoiridis G, Vlachonikolis IG. Verification of the median-to-ulnar and ulnar-to-median nerve motor fiber anastomosis in the forearm: An electrophysiological study. Clin Neurophysiol. 2003;114:94-8. 